\title{
Diplopia and Ptosis in Consequence of Probable Vipera Barani Bite
}

\author{
Muhtemel Vipera Barani Isııı̆ı Sonucunda Diplopi ve Pitozis
}

\author{
Süha Türkmen', Yunus Karaca', Özgür Tatlı2, Nurhak Aksüt', Ufuk Bülbül \\ 'Department of Emergency Medicine, Karadeniz Technical University Faculty of Medicine, Trabzon, Turkey \\ 2Department of Emergency Medicine, Trabzon Training and Research Hospital, Trabzon, Turkey \\ ${ }^{3}$ Department of Zoology, Karadeniz Technical University Faculty of Biology, Trabzon, Turkey
}

\section{ABSTRACT}

Introduction: Snake bites in Turkey are generally from nonvenomous species. However, injuries caused by venomous snakes are occasionally encountered. The family Viperidae (vipers) account for all of these injuries. Baran's Adder, Vipera barani, is a member of the family Viperidae found in the eastern Black Sea region of Turkey. Poisoning by this species may cause hematological symptoms. Although there is a possiblity of a minor neurologic effect, no case developing neurological symptoms has been previously reported in the literature.

Case Report: A 54-year-old woman was brought to the emergency department of an outlying hospital following a snake bite. Eight hours after the snake bite, she developed bilateral ptosis and blurred vision and was transferred to the emergency department of the regional referral hospital. The patient insisted that this snake is a well-known venomous snake where she lives and it was Vipera barani. Nine hours after snake bite tetanus prophylaxis and 2 ampules of European antiserum were administered. Following admission, no further complications developed.

Conclusion: Although, like other members of the family Viperidae, Vipera barani has generally been reported to result in hematologic disorders, we report that neurotoxic disorders can also occur.

Keywords: Snake bites, Baran's Adder, Vipera barani

Received: 09.12.2014 Accepted: 05.02.2015

Available Online Date: 04.03.2015

\section{ÖZET}

Giriş: Türkiye'de genellikle Yılan sokması zehirsiz türler ile olmaktadır. Ancak, zehirli yılanlar neden olduğu yaralanmalara bazen rastlanır. Bunların hepsinden Viperidae (engerek) ailesi sorumludur. Baran Adder, Baran engereği, Türkiye'nin Doğu Karadeniz bölgesinde bulunan Viperidae ailesinin bir üyesidir. Bu türler tarafından zehirlenmesi hematolojik belirtilere neden olabilir. Minör nörolojik etkisi olasılıkları olmasına rağmen daha önce nörolojik belirtiler gelişmiş hiçbir vaka literatürde bildirilmemiştir.

Olgu Sunumu: 54 yaşındaki bir kadın, bir yılan ısırığı takiben perifer bir hastanenin acil servisine getirildi. Hastada yılan ısırığından sekiz saat sonra, bilateral pitozis ve bulanık görme gelişti ve hasta bölge referans hastanenin acil servisine transfer edildi. Hasta bu yılanın yaşadığı bölgede iyi bilinen zehirli yılan ve Baran engereği olduğunda ısrar etti. Yılan ısırmasından dokuz saat tetanoz profilaksisi ve 2 ampul Avrupa antiserum uygulandı. Başvuru sonrasında, başka hiçbir komplikasyon gelişti.

Sonuç: Viperidae ailesinin diğer üyeleri gibi Baran engereğinin de genellikle hematolojik bulgulara neden olduğu bildirilmiştir. Biz nörotoksik bulgular ortaya çıkabileceğini bildirdik.

Anahtar Kelimeler: Yılan ısırığı, Baran's Adder, Vipera barani

Geliş Tarihi: 09.12.2014 Kabul Tarihi: 05.02.2015

Çevrimiçi Yayın Tarihi: 04.03.2015

\section{Introduction}

Snake bites in Turkey are seen more commonly in the summer months and in the eastern region of Turkey. Bites from nonvenomous snakes are frequent in the eastern Black Sea region of Turkey, whereas bites from venomous snakes are relatively rare. Two hundred of the 3000 species of snakes on the earth are dangerous to humans. Fifty-five species of snakes have been 
identified in Turkey, 15 of which are venous, 3 semi-venomous, and the rest are non-venomous. The venomous snakes in Turkey consist of 14 species of adder from the family Viperidae and one species of cobra (desert cobra) from the family Elapidae. Viperidae (adders) are responsible for almost all poisonous snake bites in Turkey. Vipera barani was first described by a Turkish biologist and is known as Baran's Adder or the Turkish Viper in English (1).

\section{Case Report}

A 54-year-old woman was brought to the emergency department of an outlying hospital following a snake bite. From the history, it was learned that a snake had bitten her right ankle while she was working in a field. The patient thought the snake may be poisonous and had cut the bitten area with a scythe to prevent the venom spreading through her body. Physical examination at time of presentation was normal. The patient was placed under observation in the emergency ward. Eight hours after the snake bite, she developed bilateral ptosis and blurred vision and was transferred to the emergency department of the regional referral hospital. On initial evaluation in our emergency department, there was a superficial laceration, swelling, and hyperemia over the lateral malleolus of the right ankle. On neurological examination she was lucid, oriented, and cooperative. Glasgow Coma Score was 15. Ptosis was present in both eyes (Figure 1). There was also diplopia and subjective blurred vision. Formal visual acuity testing was not performed. Blood pressure was 120/80 mmHg, heart rate 87 beats/ $\mathrm{min}$, and respiratory rate 18 breaths/min. There were no other neurologic findings. Her brain tomography was normal. From the history, it is learned that the snake was $50 \mathrm{~cm}$ in length, black, and with a triangular-shaped head. The patient insisted that this snake is a well-known venomous snake where she lives and it was Vipera barani. We interviewed a biologist who specifically studies snakes in our university about the type of snake. This biologist also thought it was probably Vipera barani. Nine hours after the snake bite, tetanus prophylaxis and two ampules of Viper Venom Antiserum European antivenom were administered. The patient was then hospitalized in the infectious disease ward. Following admission, no further complications developed. By the third hospital day, the patient was asymptomatic and was discharged home.

\section{Discussion}

Vipera barani is an extremely rare viper known in only a few areas of Turkey. The type specimen was described from the area of Adapazarı in north-western Anatolia. Franzen \& Heckes subsequently reported the species in two locations in the Black Sea Mountains in northeastern Turkey. They also provided information about the species' habitat. Baran et al. (2) added information from two additional specimens of Vipera barani found in north-eastern Turkey. Vipera barani adults are generally $40-\mathrm{cm}$ long, with a reported maximum length of $59 \mathrm{~cm}$. The body is medium-thick and the head is large and sub-triangular. The nostrils are broad and located in the middle part of the nose. The eyes are medium-sized with vertical elliptical pupils. The top of the head is covered in a combination of scales and small plates. The body scales are keeled. In normal colored animals, the back is gray-brown, with dark patches along the neck. Some of

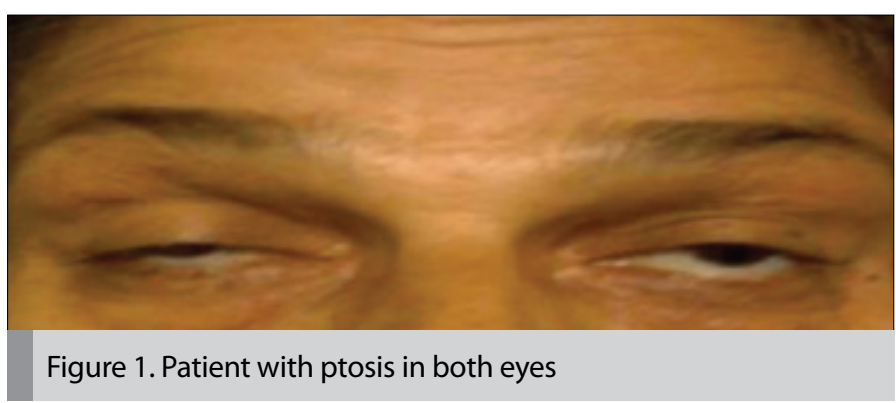

the patches combine to form a zig-zag stripe. In some, however, these patches are separate. In all-black specimens, there are white spots on the upper lip scales and at the edges of the tip of the head. The tip of the tail is yellow-spotted. It feeds on rodents and lizards in stony regions with short plant cover (3). While there have been reports of hematological symptoms developing as a result of Vipera barani bites, we encountered no case with neurological symptoms in the literature.

Generally, factors such as victim's age, body mass, the region bitten, and the victim's state of activity at the time of and after the bite affect the severity of snake poisoning. The extremities are affected in more than $90 \%$ of snake bites. Head and body bites are rare but more dangerous (4). Snake venom may give rise to local or systemic reactions (5). Neurological findings that can be seen after snake bites include fatigue, weakness, dizziness, blurred vision, and ptosis (6). Various phospholipase A2 enzyme species are thought to be responsible for this neurotoxicity (7). Hematologic and local findings are generally encountered as a result of these bites. It has also been reported that mild neurologic symptoms may be seen in bites by some members of the family Viperidae (4).

With snake bites, efforts must be made to calm the patient and to permit as little movement as possible (8). With extreme bites, the extremity must be kept at heart level if possible, and rings and similar items should be removed (4).

Because of its allergic and anaphylaxis potential, snake venom antiserum must be used only in selected patients. Anti-serum treatment is recommended for patients with systemic findings or with local tissue reactions such as a compartment syndrome (9). Three types of European and African manufactured snake antivenom are used in Turkey. The initial recommended dose is two ampules in Europe and Turkey. The dose may be increased if required. In publications in America and Asia, the initial snake anti-serum dose is 5-10 ampules (10). While administering antivenom, epinephrine should be immediately available and any complications should be closely monitored.

\section{Conclusion}

Although, like other members of the family Viperidae, Vipera barani bites cause hematologic disorders, it can also cause neurotoxic disorders.

Informed Consent: Written informed consent was obtained from patient who participated in this case. 
Peer-review: Externally peer-reviewed.

Author Contributions: Concept - S.T.; Supervision - Ö.T.; Literature Review Y.K.; Writer - S.T., U.B.; Critical Review - N.A., Ö.T.

Conflict of Interest: No conflict of interest was declared by the authors.

Financial Disclosure: The authors declared that this study has received no financial support.

Hasta Onamı: Written informed consent was obtained from patient who participated in this case. Hakem Değerlendirmesi: Dış bağımsız.

Yazar Katkıları: Fikir - S.T.; Denetleme - Ö.T.; Literatür taraması - Y.K.; Yazıyı yazan - S.T., U.B; Eleştirel İnceleme - N.A.; Ö.T.

Çıkar Çatışması: Yazarlar çıkar çatışması bildirmemişlerdir.

Finansal Destek: Yazarlar bu çalışma için finansal destek almadıklarını beyan etmişlerdir.

\section{References}

1. AdaMerOs Herptil Türkiye. Vipera Addler. Available at: www.turkherptil. org. Accessed; April 16, 2013
2. Baran I, Joger U, Kutrup B, Türkozan O. On new specimens of Vipera barani Bohme \& Joger, 1983, from northeastern Anatolia, and implications for the validity of Vipera pontica Billing, Nilson \& Sattler, 1990 (Reptilia, Viperidea). Zoology in the Middle East 2001; 23: 47-53. [CrossRef]

3. Baran I. Türkiye Amfibi ve Sürüngenleri. TÜBiTAK Popüler Bilim Kitapları. 2005. p.165.

4. Milani Júnior R, Jorge MT, de Campos FP, Martins FP, Bousso A, Cardoso JL, et al. Snake bites by the jararacuçu (Bothrops jararacussu): clinicopathological studie of 29 proven cases in Sao Paulo State, Brazil. Q J Med 1997; 90: 323-34. [CrossRef]

5. Sung CK, Hah MC. A case of extraocular muscle paresis by viper bite. J Korean Ophthalmol Soc 1981; 22: 261-3.

6. Gold BS, Winger WA. Snake venom poisoning in the United States: a review of therapeutic practice. South Med J. 1994; 87: 579-89. [CrossRef]

7. Takeshita T, Yamada K, Hanada M, Ueda NO. Extraocular Muscle Paresis Caused by Snakebite. Kobe J Med Sci 2003; 49: 11-5.

8. Chang KP, Lai CS, Lin SD. Management of poisonous snake bites in Southern Taiwan. Kaohsiung J Med Sci 2007; 23: 511-8. [CrossRef]

9. Cakir B, Cobanoglu B, Aygit A. Yılan ısırığına bağlı nekroz olgusu. ADÜ Tıp Fakültesi Dergisi 2009; 10: 51-4.

10. Köse R. Yılan zehirlenmelerinin tedavisi: Yirmi bir olgunun incelenmesi. Ulus Travma Acil Cerrahi Derg 2007; 13: 307-12. 